\title{
Mükelleflerin Vergiden Kaçınma Algısı ve Demografik Belirleyicileri Üzerine Bir Araştırma: Isparta Örneği
}

Serdar ÇICCEK, Department of Public Finance, Faculty of Economics and Administrative Sciences, Suleyman Demirel University, Turkey; e-mail: serdarcicek@sdu.edu.tr

Jale SABBA $\breve{G}$, Department of Public Finance, Institute of Social Sciences, Suleyman Demirel University, Turkey; e-mail: jalesabbag@hotmail.com

\section{A Survey on Tax Avoidance Perception of Taxpayers and its Demographic Determinants: A Case of Isparta}

\begin{abstract}
In this study, a questionnaire has been created for measuring tax avoidance how find place in the minds of taxpayers, also attitudes and behaviors of taxpayers against to tax. Data of obtained from by using face-to-face questionnaires method applied are interpreted with frequency analysis and cross tables on 400 participants who the income taxpayers of Isparta province. According to the obtained results; the majority of the taxpayers have seen to tax avoidance as a rational behavior and they have expressed that their preferences can change for consumption or investment in order to pay less tax. Taxpayers, if low tax rates will be applied, express to reviewing the preferred investment location, whereas not take kindly to change the settlement. Attitudes and behaviors of towards the tax avoidance more affected from variables especially such as the education, age, gender.
\end{abstract}

Keywords $\quad$ : Tax Psychology, Tax Avoidance, Taxpayers'Attitudes.

JEL Classification Codes : $\quad$ H20, H26.

\section{$\ddot{\mathbf{O} z}$}

$\mathrm{Bu}$ çalışmada, vergiden kaçınmanın mükellef zihninde nasıl yer bulduğunu, ayrıca mükelleflerin vergiye karşı tutum ve davranışlarını ölçmek amacıyla bir anket formu oluşturulmuştur. Isparta ilinde gelir vergisi mükellefi olan 400 katılımcıya yüz yüze anket yöntemi kullanılarak uygulanan anketten elde edilen veriler frekans analizi ve çapraz tablolarla yorumlanmıştır. Bulgulara göre; mükelleflerin çoğunluğu vergiden kaçınmayı rasyonel bir davranış olarak görmekte ve daha az vergi ödemek amacıyla tüketim veya yatırım tercihlerini değiştirebileceklerini ifade etmektedirler. Mükellefler, düşük vergi oranları uygulanacak olursa, yatırım yeri tercihini gözden geçirebileceğini ifade etmekte, buna karşılık yerleşim yerini değiştirmeye sıcak bakmamaktadır. Vergiden kaçınmaya yönelik tutum ve davranışların özellikle eğitim durumu, yaş, cinsiyet gibi değişkenlerden daha fazla etkilendiği görülmüştür.

\section{Anahtar Sözcükler $\quad$ : Vergi Psikolojisi, Vergiden Kaçınma, Vergi Mükelleflerinin} Tutumları. 


\section{Giriş}

Vergi politikalarının ve vergiyle ilgili hukuki düzenlemelerin tasarlanmasında mükelleflerin davranışlarının göz önünde bulundurulması siyaset kurumu ve bürokrasi açısından vazgeçilmez bir bilgi niteliğindedir. Bu çalışmada, Isparta ilinde gerçek ve basit usuldeki gelir vergisi mükelleflerinin vergiden kaçınma konusundaki algılarının belirlenmesi amaçlanmıştır. Bu temel amacın yanı sıra mükelleflerin vergiden kaçınma ile ilgili algılarının yaş, cinsiyet, medeni durum, eğitim durumu, iş tecrübesi, gelir durumu gibi demografik değişkenlere bağlı olarak nasıl ve hangi yönde değişiklik gösterdiğinin ortaya konulması amaçlanmaktadır.

Çalışmada, Isparta ilinde yer alan gelir vergisine tabi olan mükelleflere anket uygulaması yapılmıştır. Araştırma kapsamında gerçek ve basit usuldeki toplam 400 mükellefe anket formu uygulanmıştır. Anket uygulanan mükellefler tesadüfi örneklem yöntemiyle belirlenmiştir. Anket formu iki bölümden oluşmuştur. Birinci bölüm, mükelleflerin demografik özelliklerini ve vergi hakkındaki düşüncelerini, ikinci bölüm ise mükelleflerin vergiden kaçınma algılarını belirlemeye yönelik sorulardan oluşmuştur. Anketlerdeki ifadeler kodlanıp SPSS 21.0 paket programına yüklenerek, elde edilen verilere göre yüzde ve çapraz tablo analizi yapılmıştır.

\section{Literatür}

\subsection{Vergiden Kaçınma}

Vergiden kaçınma, vergi kanunlarındaki boşluklardan yararlanarak, kanuni yollarla vergi ödemelerini azaltmak için yapılan bir girişim olarak ifade edilebilir (Schneider vd., 2001: 3). Kaçınma, kanunlardaki boşluklardan yararlanma şeklinde olabileceği gibi, vergiyi doğuran olaya sebebiyet vermeme şeklinde de gerçekleştirilebilir (Nadaroğlu, 1996: 279). Örneğin, daha düşük bir oranda vergilendirilen sermaye geliri tercih edildiğinde vergiyi doğuran olaya sebebiyet verilmemiş olunmaktadır. Vergiden kaçınmaya teşebbüs etmede vergi mükellefinin duygusal davranması konusunda kaygılanması için herhangi bir neden yoktur; tam aksine mükellefin istediği vergi indirimini alması için yapacağı işlemler hakkında bilgi sahibi olması gerekir (Sandmo, 2004: 4).

Vergiden kaçınma, kanunları ihlal etmek veya kanunlara aldırmamak şeklinde değil de kanun hükümlerinin kötüye kullanımı veya istismar edilmesi şeklinde de karakterize edilebilir (Review of Business Taxation, 1999'den akt. Zhang, 2007: 9). Vergiden kaçınma, kişinin kendi yararına olmak üzere vergi kanunlarının sömürüsünü içerir, dolayısıyla vergiden kaçınma terimi, vergi kanunları içinde tanımlanamaz (Tooma, 2008: 12). Bir başka deyişle, vergiden kaçınma, parlamentoda kanun tasarlanırken veya kabul edilirken beklenen amacın tersine hukuk manipülasyonunu içerebilmektedir ve bu sebeple kanun hükmünün özünden sapılmaktadır (Review of Business Taxation, 1999'den akt. Zhang, 2007: 9). 
Vergi kaçakçılığı ve vergiden kaçınma kavramlarının birbirine yaklaştığı, aradaki farkın belirsiz hale dönüşmesi ile ilgili olarak literatürde vergiden kaçınma kavramı ile ilgili olarak farklı ülkelerde, farklı sıfatlar kullanılabilmekte ya da farklı tanımlamalar yapılabilmektedir. Örneğin, Avustralya'da "agresif vergi planlaması”, Güney Afrika'da "müsaade edilmez ya da kötü niyetli vergiden kaçınma", Yeni Zelanda'da ve İngiltere'de "kabul edilemez vergiden kaçınma" olarak adlandırılır ve Amerika'da ise "kötü niyetli vergi sığınakları" gibi terimler sıklıkla kullanılmaktadır. OECD, vergi kaçakçılığının, vergi yükümlülüğünün gizlenmesi ya da göz ardı edilmesi yoluyla gerçekleşen yasadışı eylemler olduğunu belirtmektedir. Vergiden kaçınmayı ise, vergi mükellefinin yükümlülügünü azaltmak amacıyla yaptığı eylemlerin yasal olmasına rağmen genellikle hukukun amacı ile ters düşmesi şeklinde ifade etmektedir (Evans, 2009: 531). AB'ye üye devletlerde ise bazı vergiden kaçınma türleri vergi mahkemeleri tarafından yasal olarak kabul edilirken, bazıları da yasal olarak kabul edilmez (O’Shea, 2010: 77).

Vergi kaçırma ve vergiden kaçınma gibi olaylar bütün ülkelerde görülebilmesine karşın, özellikle gelişmekte olan ekonomilerde kurumsal yapıların zayıf olması ve mücadele konusunda yeterli deneyimin olmaması nedeniyle daha fazla gerçekleşmektedir (Lampreave, 2013: 51). Bununla birlikte bu olaylar vergi sisteminin temel amaçlarından olan gelirin yükseltilmesi ve gelir ve servetin dağıtımı için de bir tehdit oluşturmaktadır (Taylor, 2006: 9).

Düşük vergi ahlakı, vergi karşılığında alınan kamu hizmetinin düşük kalitede olması, vergi sistemi ve vergi algısı, düşük şeffaflık ve kamu kurumlarının hesap verebilirliği, yolsuzluğun yüksek seviyede olması, hukukun üstünlüğünün ve mali yarg1 yetkisinin eksikliği, yüksek uyum maliyetleri, vergi kanunlarının zayıf şekilde uygulanması, zayıf vergi idaresi gibi nedenler vergiden kaçınmaya yol açabilen bazı durumlardır (Hoque vd., 2013: 9). Kaçınmaya neden olabilecek kanun hükümlerinin karşılaşılması muhtemel durumlara cevap veremeyecek nitelikte düzenlenmiş olmaları, ülkenin ekonomik, sosyal, politik koşulları, mükelleflerin psikolojik durumları, vergi kanunlarının getiriliş amacını gerçekleştirme açısından yetersiz kalabilmesi vergiden kaçınmaya sebep olan diğer faktörler olarak sıralanabilir (Eker, 1999: 159-160). Bu şartlarda vergi yükümlülüğünü azaltmak isteyen mükellefler, vergi kaçırmak yerine vergiden kaçınmaya da yönelebilmektedir. Birçok ülkede, vergileri en aza indirip mali işleri düzenlemek için tamamen yasal olan vergi sığınakları ve vergiden kaçınma stratejilerinin mevcut olduğu görülmektedir (Webley, 1991: 135). Bir ülkede birbirinin yerine ikame edilebilecek mallar farklı oranlarda vergilendirilirse, sistem daha az vergi yükü içereni seçmek için mükellefleri cesaretlendirmektedir. Özellikle farklı vergi yüklerine tabi ve birbirine benzer sayısız biçimler alabilen ekonomik işlemler ve finansal araçlar çerçevesinde vergiden kaçınma belirginleşebilmektedir (Bowler, 2009: 15).

\subsection{Mükelleflerin Vergiye Karşı Davranışları ve Demografik Faktörler}

Vergilendirmenin etkili bir şekilde oluşturulması açısından, mükelleflerin davranışlarının göz önünde bulundurulması gerekmektedir (Akdoğan, 2011: 188). Yere, 
zamana ve bireylere göre değişiklik gösteren bir yapıya sahip olan insan davranışları vergilerden etkilenebileceği gibi vergileri de doğal olarak etkileyecektir (Edizdoğan vd., 2012: 227). Bu bağlamda vergilerin yükümlüler üzerindeki psikolojik etkileri ve onların davranışlarına nasıl yön verdiği konusu vergi psikolojisi alanına girmektedir (Çiçek vd., 2008: 21).

Vergi ile insan psikolojisi arasındaki ilişkileri inceleyen maliyecilerin başında Alman bilim adamı G. Schmölders gelmektedir. G. Schmölders başta olmak üzere birçok maliyeci ile birlikte vergi psikolojisi alanında bazı çalışmalar yürütülmüştür ve 1970'li yıllardan sonra vergi psikolojisi alanındaki çalışmalar giderek artmıştır (Aktan, 2012: 15).

Vergi psikolojisi, vergileme açısından oldukça önem taşımaktadır. Vergisel olayların insan tutum ve davranışları üzerindeki etkilerini inceleyen bir araştırma alanı olan vergi psikolojisi (Aktan, 2012: 14), vergi ile ilgili olan bireysel ve toplumsal psikolojik olayları inceler (Çataloluk, 2008: 215).

Her mükellefin içinde bulunduğu psikolojik durum ve vergiye yaklaşımı aynı değildir (Şin, 2005: 129). Bu tür farklılıklar neticesinde mükelleflerin vergiye uyumları üzerinde etkili olan faktörlerin belirlenmesi ve vergi politikaları konusunda bir takım düzenlemelerin yapılması son derece önemlidir (İpek \& Kaynar, 2009: 117). Bu bağlamda, mükelleflerin yaş, cinsiyet, eğitim durumu, medeni hal, meslek gibi demografik özellikleri, vergi karşısında gösterdiği eğilimler üzerinde etkili olabilmektedir (Saraçoğlu, 2008: 16).

Yaş faktörü vergi uyumu ile yakından ilişkilidir. Yapılan çalışmalar genç yaştaki mükelleflerin daha yüksek bir hayat standardına ulaşmak, kazançlarının büyük bir kısmını tüketime ayırmak, aile kurup daha yüksek bir hayat standardına kavuşmak gibi istekleri ve risk alma güdülerinin yaşlı mükelleflere göre güçlü olması nedeniyle vergiye uyumsuzluğun genç mükelleflerde daha fazla olduğu görülmektedir. İleri yaş düzeyinde bulunan bireyler, belirli bir hayat seviyesine ulaştıkları için bunun devamı yönünde bir düşünceye sahip olmaları dolayısıyla diğer yaştaki gruplara nazaran vergiye karşı daha uyumlu davranmaktadırlar (Çataloluk, 2008: 221). Benzer şekilde, Jackson ve Milliron (1986) tarafından gözlenen çalışmaların çoğunda, yaşlı mükelleflerin genç mükelleflere göre daha uyumlu oldukları saptanmıştır (Jackson \& Milliron, 2002: 62). Ayrıca Tittle'ın 1980 yılında yaptığı bir çalışmada genç mükelleflerin daha fazla risk aldığı, cezalara daha az duyarlı olduğu gözlemlenmiştir. Ancak, yaş ile vergi uyumu arasında ilişki bulunmadığını belirten çalışmalar da mevcuttur (Tittle, 1980'den akt. Devos, 2008: 10).

Cinsiyet, mükelleflerin tutum ve davranışlarını etkileyen önemli bir faktördür (Jackson \& Milliron, 1986'dan akt. Kasipillai \& Abdul Jabbar, 2006: 74). Jackson ve Milliron (2002: 63) tarafından yapılan çalışmada, kadın mükelleflerin erkek mükelleflere göre daha uyumlu olduğu belirtilmiştir. Richardson ve Sawyer, kadınlar ve erkekler arasındaki bu uyum farkının kadınların daha bağımsız hale gelmesi ve geleneksel olmayan kadın neslinin ortaya çıkmasıyla daraldığını gözlemlemiştir (Devos, 2008: 9). 
Eğitim faktörü incelendiğinde genel olarak, eğitim düzeyinin yüksekliğinin vergiye uyumu kolaylaştırdığı düşünülmektedir (İpek \& Kaynar, 2009: 120). Öğrenim düzeyi yüksek olan mükelleflerin yasaları daha kolay algıladıkları ve bu sayede de yapılan değişikliklere daha hızlı uyum sağladıkları (Yeniçeri, 2004: 919), vergilerin ekonomik ve sosyal işlevleri konusunda daha bilinçli oldukları ve vergi kaçırma eğilimlerinin daha düşük seviyelerde seyrettiği görülmüştür (Aşan, 2014: 71). Vogel'in araştırma bulgularına göre; daha az eğitimli mükelleflerin vergiye daha az uyumlu olduklarını, vergi düzenlemeleri hakkında daha az bilgiye sahip olduklarını ve daha sık yardıma ihtiyaç duyduklarını göstermektedir (Vogel, 1974: 27'den akt. Ömürbek vd., 2007: 105).

Medeni durum faktörü incelendiğinde, evli olan mükelleflerin, bekâr mükelleflere göre daha uyumlu olduğu tespit edilmiştir. Bu durum kısmen kadınların erkeklere oranla daha fazla vergiye uyumlu olduğu gerçeği ile de açıklanabilir (Asante \& Baba, 2011: 88).

Vergi mükellefinin mesleğinin, vergiye karşı oluşan tepkiler üzerindeki etkileri büyüktür. Mesleklerin vergiden kaçınma olasılığı farklı olduğu gibi uyum davranışı da meslek grupları arasında farklıdır (Hashimzade vd., 2011: 1).

\section{Araştırma}

\subsection{Araștırmanın Amacı}

Vergiye karşı gösterilen tutum ve davranışların bir parçası olarak mükelleflerin vergiden kaçınma algısını ve bu algıya hangi demografik faktörlerin ne yönde etki gösterdiğini araştırmaktır.

\subsection{Araştırmanın Kapsamı ve Yöntemi}

Isparta ilindeki gelir vergisine tabi olan işletme yöneticileri araştırma evrenini oluşturmuştur. Örneklem büyüklüğünün saptanmasında $\% 95$ güven aralığında, $\pm \% 5$ hata payı ve 0,50 nüfus oranına göre hesaplanan 381 kişiye anket yapılması uygun görülmüștür (Kurtuluş, 1998: 235). Araştırma kapsamında toplam 400 kişiye geliştirilen anket formu uygulanmıştır. Anket formu araştırıcının kendisi tarafından uygulanmıştır. Anket uygulanan mükellefler tesadüfi örneklem yöntemiyle belirlenmiştir. Anket formu iki bölümden oluşmuştur. Birinci bölüm, mükelleflerin demografik özelliklerini ve vergi hakkındaki düşüncelerini, ikinci bölüm ise mükelleflerin vergiden kaçınma algılarını belirlemeye yönelik sorulardan oluşmuştur. Algıya yönelik görüşlerin ölçülmesinde 5'li likert ölçeği kullanılmıştır. Beşli likert ölçeğinin kullanıldığı çalışmada, güvenilirlik analizinin saptanmasında ölçeği oluşturan maddelerin test içindeki ortalama korelasyonlarının hesaplanması yoluyla, ölçümün içsel tutarlılığını gösteren alfa katsayısı (Cronbach's Alpha) kullanılmıştır. Çalışmada testin güvenilirlik katsayısı 0.75 olduğu belirlenmiştir. 
Doldurulan anketlerdeki ifadeler kodlanıp SPSS 21.0 paket programına yüklenerek elde edilen veriler yüzde ve çapraz tablo analizleri ile değerlendirilmiştir. Bağımsız değişkenlere göre vergiden kaçınma konusundaki düşünceleri belirlemek amacıyla parametrik olmayan testlerden ki kare testi kullanılmıştır. P değeri 0,05'ten küçük ya da eşit ise farklılı̆̆ın istatistiksel açıdan anlamlı olduğu kabul edilmiştir (Kurtuluş, 1998: 235).

\subsection{Araştırma Bulguları}

\subsubsection{Katılımcılara Ait Demografik Bilgilerin Frekans Dağılımı}

Aşağıda yer alan bulgular çalışma evrenini temsil ettiği varsayılan örneklem kitlenin demografik özelliklerini ortaya koymakta ve ele alınan her bir demografik özellik ayrı ayrı irdelenmektedir.

Ankete katılan mükelleflerin yaş aralıklarını gösteren Tablo 1 incelendiğinde, mükelleflerin çoğunluğunun $30-39$ yaş aralığında $(\% 33,5)$ olduğu belirlenmiştir. Bu yaş grubunu $40-49$ yaş grubu $(\% 24,7)$ takip etmektedir. Tablodan da anlaşılabileceği gibi, ankete katılan mükelleflerin çoğunluğunu genç ve orta yaş grubu oluşturmaktadır.

Tablo: 1

\section{Mükelleflerin Yaş Gruplarına Göre Frekans Dağılımı}

\begin{tabular}{|c|c|c|}
\hline Yaş Aralı̆̆ & Frekans (S) & Yüzde (\%) \\
\hline $20-29$ & 92 & 23 \\
\hline $30-39$ & 134 & 33,5 \\
\hline $40-49$ & 99 & 24,7 \\
\hline $50-59$ & 51 & 12,8 \\
\hline $60-69$ & 24 & 6 \\
\hline Toplam & $\mathbf{4 0 0}$ & $\mathbf{1 0 0}$ \\
\hline
\end{tabular}

Tablo: 2

Mükelleflerin Cinsiyetlerine Göre Frekans Dağglımı

\begin{tabular}{|c|c|c|}
\hline Cinsiyet & Frekans (S) & Yüzde (\%) \\
\hline Kadın & 46 & 11,5 \\
\hline Erkek & 354 & 88,5 \\
\hline Toplam & $\mathbf{4 0 0}$ & $\mathbf{1 0 0}$ \\
\hline
\end{tabular}

Mükelleflerin cinsiyetlerine göre dağılımı incelendiğinde, sonuçlar işletme yönetiminde erkek hâkimiyetinin ön planda olduğunu göstermektedir. Ankete katılan mükelleflerin büyük bir çoğunluğunun $(\% 88,5)$ erkek olduğu göze çarpmaktadır. Kadın katılımcıların oranı sadece $\% 11,5^{\prime}$ tir (Tablo 2). 
Evli mükelleflerin bekâr mükelleflere oranla daha fazla sorumluluk üstlenmeleri ve yaşam standardını yükseltme isteği kişinin vergiye karşı tutumunu etkileyebilir (İnanç, 2012: 36). Tablo 3'te mükelleflerin medeni durumlarına göre dağılımları görülmektedir. Ankete katılan mükelleflerin büyük bir çoğunluğu (\%77) evli iken, bekârların oranı ise (\%23) daha düşük bir orana sahiptir.

Tablo: 3

Mükelleflerin Medeni Durumlarına Göre Frekans Dağılımı

\begin{tabular}{|c|c|c|}
\hline Medeni Durum & Frekans (S) & Yüzde (\%) \\
\hline Evli & 308 & 77 \\
\hline Bekâr & 92 & 23 \\
\hline Toplam & $\mathbf{4 0 0}$ & $\mathbf{1 0 0}$ \\
\hline
\end{tabular}

Tablo 4'te mükelleflerin eğitim düzeylerine göre dağılımları incelendiğinde en yüksek eğitim oranının lise düzeyinde (\%34) olduğu görülürken, bunu lisans düzeyindekilerin $(\% 24,3)$ takip ettiği görülmektedir. İlkokul mezunlarının oranı da küçümsenmeyecek kadar yüksektir $(\% 13,8)$.

Tablo: 4

Mükelleflerin Eğitim Durumlarına Göre Frekans Dağılımı

\begin{tabular}{|c|c|c|}
\hline Ĕ̈itim Durumu & Frekans (S) & Yüzde (\%) \\
\hline İlkokul & 55 & 13,8 \\
\hline Ortaokul & 45 & 11,2 \\
\hline Lise & 136 & 34 \\
\hline Önlisans & 49 & 12,2 \\
\hline Lisans & 97 & 24,3 \\
\hline Yüksek lisans-doktora & 18 & 4,5 \\
\hline Toplam & $\mathbf{4 0 0}$ & $\mathbf{1 0 0}$ \\
\hline
\end{tabular}

Tablo: 5

Mükelleflerin İş Tecrübelerine Göre Frekans Dağılımı

\begin{tabular}{|c|c|c|}
\hline İs Tecrübesi (YII) & Frekans (S) & Yüzde (\%) \\
\hline $0-5$ & 69 & 17,2 \\
\hline $6-10$ & 74 & 18,5 \\
\hline $11-15$ & 91 & 22,8 \\
\hline $16-20$ & 72 & 18 \\
\hline 25 yıldan fazla & 94 & 23,5 \\
\hline Toplam & $\mathbf{4 0 0}$ & $\mathbf{1 0 0}$ \\
\hline
\end{tabular}

Tablo 5'te ankete katılan mükelleflerin iş tecrübelerine göre dağılımları görülmektedir. Ankete katılan mükelleflerin çoğunluğunun 25 yıl ve üzeri iş tecrübesine sahip oldukları belirlenmiştir. İkinci sırada ise mükelleflerin 11-15 yıl iş tecrübesine $(\% 22,8)$ sahip oldukları saptanmıştır. 
Mükelleflerin gelir durumları yapılan araştırma açısından önemlidir. Çünkü mükelleflerin gelir seviyesi ile vergiye karşı göstermiş olduğu tutum arasında önemli bir ilişki vardır (Alkan, 2009: 77). Tablo 6'da, mükelleflerin aylık gelir durumlarına bakıldığında, büyük çoğunluğunun 1.000-1.999 TL arasında $(\% 40,2)$ gelire sahip oldukları görülmüştür.

Tablo: 6

Mükelleflerin Gelir Durumlarına Göre Frekans Dağılımı

\begin{tabular}{|c|c|c|}
\hline Aylık Gelir (TL) & Frekans (S) & Yüzde (\%) \\
\hline $500-999$ & 45 & 11,2 \\
\hline $1.000-1.999$ & 161 & 40,2 \\
\hline $2.000-2.999$ & 91 & 22,8 \\
\hline $3.000-3.999$ & 50 & 12,5 \\
\hline 4.000 ve üzeri & 53 & 13,3 \\
\hline Toplam & $\mathbf{4 0 0}$ & $\mathbf{1 0 0}$ \\
\hline
\end{tabular}

Tablo 7'de mükelleflerin mükellefiyet türleri incelendiğinde ankete katılanların \%77,3'ünü gerçek usuldeki mükellefler, \%22,7'sini de basit usuldeki mükellefler oluşturmaktadır.

Tablo: 7

\section{Mükelleflerin Mükellefiyet Türüne Göre Frekans Dağılımı}

\begin{tabular}{|c|c|c|}
\hline Mükellefiyet Türü & Frekans (S) & Yüzde (\%) \\
\hline Gerçek Usul & 309 & 77,3 \\
\hline Basit Usul & 91 & 22,7 \\
\hline Toplam & $\mathbf{4 0 0}$ & $\mathbf{1 0 0}$ \\
\hline
\end{tabular}

Mükelleflerin vergi karşısındaki tepkilerinin derecesi ile vergi oranları arasında doğrusal bir ilişki bulunmaktadır. Vergi oranlarının artması ile üstlenilen vergi yükü de artmaktadır. Artan vergi yükü karşısında geliri azalan mükellef de tüketimini azaltmak ve tasarruftan vazgeçmek durumuyla karşı karşıya kalabilir (Gök, 2007: 147). Yapılan çalışmada ankete katılan mükelleflerin "Ülkemizde vergi oranlarl size göre yüksek midir?" sorusuna verdikleri cevaplar Tablo 8'de gösterilmiştir. Buna göre, ankete katılanların 226's1 $(\% 56,5)$ vergi oranlarının yüksek olduğunu, 126'sı $(\% 31,5)$ vergi oranlarının çok yüksek olduğunu belirtmiştir. Yıldız'ın (2011), İstanbul Vergi Dairesi Başkanlığı Sarıgazi Vergi Dairesi Müdürlüğü'ne bağl1 376 mükellef üzerinde yaptığı çalışmaya göre, mükelleflerin büyük bir çoğunluğu $(\% 88,56)$ Türkiye'deki vergi oranlarının yüksek olduğunu ifade etmiştir. Yapılan bu çalışmanın araştırmamızı destekler nitelikte olduğu söylenebilir (Yıldız, 2011: 91). 
Tablo: 8

Mükelleflerin “Ülkemizde Vergi Oranları Size Göre Yüksek Midir?” Sorusuna Verdiği Cevaplara Göre Dağılımı

\begin{tabular}{|c|c|c|}
\hline & Frekans (S) & Yüzde (\%) \\
\hline Çok yüksek & 126 & 31,5 \\
\hline Yüksek & 226 & 56,5 \\
\hline Normal & 46 & 11,4 \\
\hline Düşük & 1 & 0,3 \\
\hline Çok düşük & 1 & 0,3 \\
\hline Toplam & $\mathbf{4 0 0}$ & $\mathbf{1 0 0}$ \\
\hline
\end{tabular}

Mükelleflerin ödedikleri vergi; gelir ve servetlerinde meydana getirdiği azalma nedeniyle servetleri üzerinde maddi bir yük oluşturmaktadır. Vergi yükünün yüksek olması dolayısıyla da vergi kayıp ve kaçaklarında artış yaşanmaktadır (Yıldız vd., 2013: 131). Bu nedenle, mükelleflerin vergi yükü hakkındaki görüşleri de alınmıştır. Ankete katılan mükelleflerin "Kendi üzerinizdeki toplam vergi yükünü nasıl hissediyorsunuz?" sorusuna verdikleri cevaplar Tablo 9'da gösterilmiştir. Buna göre, ankete katılanların 207'si $(\% 51,8)$ üzerindeki vergi yükünü ağır hissettiğini, 118'i (\%29,5) vergi yükünü çok ağır hissettiğini belirtmiştir. Daha önce yapılan çalışmalar incelendiğinde araştırmamızı destekler nitelikte verilerin olduğu gözlenmiştir. Örneğin, Yenigün'ün (2012), İstanbul ili sınırları içerisinde faaliyet gösteren ve 560 kişilik örnek kitleden oluşan vergi mükellefleri üzerinde yaptığı bir çalışmaya göre, mükelleflerin vergi yükünü nasıl hissettiği konusunda soru yöneltilmiş ve bu soruya mükelleflerin büyük bir çoğunluğu $(\% 48,8)$ ödedikleri vergilerin yüklerini ağır hissettiğini ifade etmiştir (Yenigün, 2012: 72-73).

Tablo: 9

\section{Mükelleflerin “Kendi Üzerinizdeki Toplam Vergi Yükünü Nasıl Hissediyorsunuz?"} Sorusuna Verdiği Cevaplara Göre Dağılımı

\begin{tabular}{|c|c|c|}
\hline & Frekans (S) & Yüzde (\%) \\
\hline Çok ă̆ır & 118 & 29,5 \\
\hline A ̆grır & 207 & 51,8 \\
\hline Normal & 74 & 18,4 \\
\hline Hafif & 1 & 0,3 \\
\hline Toplam & $\mathbf{4 0 0}$ & $\mathbf{1 0 0}$ \\
\hline
\end{tabular}

Mükellefler üzerindeki vergi yükünü azaltmak için bazı nedenlerden dolayı vergiden kaçınmanın yollarını arar. Bunlardan bazıları, verginin iktisadi güçlerinde yaratmış olduğu azalma, vergi yükünün dağılımında ortaya çıkan adaletsizlik, vergi bilinci ve vergi ahlakının yeterince yerleşmemiş olması, vergi oranlarının yüksekliği, devlete ödenen vergilerin kamu hizmeti olarak geri dönmemesi, vergi mevzuatının karmaşıklığı, vergi idaresi ve denetiminin yetersizliği ve vergiden kaçınmanın rasyonel bir davranış olması olabilir. Tablo 10'da ankete katılan mükelleflerin "Sizce mükellefler en çok hangi sebeple/sebeplerle vergiden kaçınır?" sorusuna verdikleri cevaplar gösterilmiştir. Bu soruda ankete katılanların \%21,8'i vergiden kaçınma sebebinin vergi oranlarının yüksekliğinden, 
\%20,5'i vergi yükünün dağılımında ortaya çıkan adaletsizlikten kaynaklandığını belirtmiştir.

Tablo: 10

Mükelleflerin "Sizce mükellefler en çok hangi sebeple/sebeplerle vergiden kaçınır?" Sorusuna Verdiği Cevaplara İliş̧kin Frekans Dağılımı

\begin{tabular}{|l|c|c|}
\hline & Frekans (S) & Yüzde (\%) \\
\hline İktisadi güçlerinde azalmaya neden olduğu için & 84 & 6,7 \\
\hline Vergi yükünün dağılımında ortaya çıkan adaletsizlik nedeniyle & 258 & 20,5 \\
\hline Vergi bilinci ve vergi ahlakının yeterince yerleşmemiş olması & 171 & 13,6 \\
\hline Vergi oranlarının yüksek olması & 275 & 21,8 \\
\hline Devlete ödenen vergilerin kamu hizmeti olarak geri dönmemesi & 129 & 10,2 \\
\hline Vergi mevzuatının karmaşıklığı & 127 & 10,1 \\
\hline Vergi denetiminin yetersizliği & 101 & 8,0 \\
\hline Vergi idaresinin yetersizliği & 46 & 3,7 \\
\hline Vergiden kaçınmanın rasyonel bir davranış olması & 69 & 5,5 \\
\hline Toplam & $\mathbf{1 2 6 0}$ & $\mathbf{1 0 0}$ \\
\hline
\end{tabular}

Vergi oranlarının yüksek olması nedeniyle vergi bir yük olarak görülmektedir. Çoğu zaman kişiler vergiden kaçınma yollarını aramaktadırlar. Tablo 11 'de yer alan verilere göre; ankete katılan mükelleflerin 208'i (\%51) yasal yollardan daha az vergi ödemeye çalışmanın rasyonel bir davranış olduğunu düşünmekte, $141^{\prime} \mathrm{i}(\% 35,3)$ ise bu görüşe katılmadıklarını belirtmektedir.

Tablo: 11

"Yasal yollardan daha az vergi ödemeye çalışmak rasyonel bir davranıştır" İfadesine Verilen Yanıtların Dağılımı

\begin{tabular}{|c|c|c|}
\hline & Frekans (S) & Yüzde (\%) \\
\hline Kesinlikle katıllyorum & 44 & 11 \\
\hline Kat1lyorum & 164 & 41 \\
\hline Kararsızım & 51 & 12,7 \\
\hline Katılmıyorum & 92 & 23 \\
\hline Kesinlikle katılmıyorum & 49 & 12,3 \\
\hline Toplam & $\mathbf{4 0 0}$ & $\mathbf{1 0 0}$ \\
\hline
\end{tabular}

Tablo: 12

"Vergiden kaçındığımda rahatsız olurum" İfadesine Verilen Yanıtların Dağılımı

\begin{tabular}{|c|c|c|}
\hline & Frekans (S) & Yüzde (\%) \\
\hline Kesinlikle katıllyorum & 70 & 17,5 \\
\hline Katıliyorum & 190 & 47,5 \\
\hline Kararsızım & 36 & 9 \\
\hline Katılmıyorum & 82 & 20,5 \\
\hline Kesinlikle katılmıyorum & 22 & 5,5 \\
\hline Toplam & $\mathbf{4 0 0}$ & $\mathbf{1 0 0}$ \\
\hline
\end{tabular}


Tablo 12'de yer alan verilere göre; ankete katılan mükelleflerin 260'^ (\%65) vergiden kaçındığında rahatsızlık duyduğunu belirtirken, 104'ü (\%26) bu görüşe katılmadıklarını, 36'sı (\%9) kararsız olduğunu belirtmiş̦tir. Vergi ödemenin bir ahlaki görev olduğunu bilen mükelleflerin çoğunluğu vergiden kaçındığında rahatsız olduğunu ifade etmektedir. Vergiden kaçınma durumunda dürüst olmayacakları fikri kişide huzursuzluk yaratacağından dolayı bundan rahatsız oldukları görülmektedir.

Tablo 13'de yer alan verilere göre; katılımcıların \%46,4'ü herhangi bir şey alırken daha fazla vergi ödememek için tercihini değiştirdiğini, katılımcıların \%40,3'ü ise daha fazla vergi ödememek için tercihini değiş̧tirmediğini ifade etmiştir. Katılımcıların \%13,3'ü ise kararsız kalmıştır.

Tablo: 13

"Herhangi bir şey alırken daha fazla vergi ödememek için tercihimi değiştiririm" İfadesine Verilen Yanıtların Dağılımı

\begin{tabular}{|c|c|c|}
\hline & Frekans (S) & Yüzde (\%) \\
\hline Kesinlikle kat1lyyorum & 64 & 16 \\
\hline Katıliyorum & 122 & 30,4 \\
\hline Kararsızım & 53 & 13,3 \\
\hline Katılmıyorum & 136 & 34 \\
\hline Kesinlikle katılmıyorum & 25 & 6,3 \\
\hline Toplam & $\mathbf{4 0 0}$ & $\mathbf{1 0 0}$ \\
\hline
\end{tabular}

Sıfır otomobil alımında fiyatın içinde yer alan Özel Tüketin Vergisinin yüksek olması Tablo 14'te yer alan verilere göre; katılımcıların \%71,1'inin satın alma kararını olumsuz etkilemekte, katılımcıların \%21,6'sının satın alma kararını ise olumsuz etkilememektedir. $\mathrm{Bu}$ durum, sıfır otomobil vergilerinin yüksek olması nedeniyle, mükelleflerin vergisi düşük olan sıfır otomobilleri tercih edebileceği veya ikinci el otomobil satın alma yoluna gidebileceği sonucunu ortaya çıarmaktadır.

Tablo: 14

“Otomobil tercihimde, otomobilin vergisinin (Özel Tüketim Vergisi) yüksek olması, satın alma kararımı olumsuz etkiler" İfadesine Verilen Yanıtların Dağılımı

\begin{tabular}{|c|c|c|}
\hline & Frekans (S) & Yüzde (\%) \\
\hline Kesinlikle katıllyorum & 127 & 31,7 \\
\hline Katıliyorum & 158 & 39,4 \\
\hline Kararsızım & 29 & 7,3 \\
\hline Katılmıyorum & 65 & 16,3 \\
\hline Kesinlikle katılmıyorum & 21 & 5,3 \\
\hline Toplam & $\mathbf{4 0 0}$ & $\mathbf{1 0 0}$ \\
\hline
\end{tabular}

Tablo 15'de yer alan verilere göre; katılımcıların 256'sı (\%64) “yerleşim yerini değiştirme" görüşüne katılmadığını, 106'sı $(\% 26,5)$ bu görüş̧e katıldığını ve 38'i $(\% 9,5)$ kararsız kaldığını belirtmiştir. Bu sonuçtan yola çıkılarak, mükelleflerin çoğunluğunun 
otomobil tercihini değiştirmesine rağmen, vergi oranları düşük olsa bile aidiyet bağı daha fazla belirgin olan yaşam yerini değiştirmekte katı durduğu söylenebilir.

Tablo: 15

“Türkiye'nin başka bir ilinde, daha düşük vergi oranlarının uygulandığını bilsem, yerleşim yerimi değiştiririm” İfadesine Verilen Yanıtların Dağılımı

\begin{tabular}{|c|c|c|}
\hline & Frekans (S) & Yüzde (\%) \\
\hline Kesinlikle katıliyorum & 58 & 14,5 \\
\hline Kat1liyorum & 48 & 12,0 \\
\hline Kararsızım & 38 & 9,5 \\
\hline Katılmıyorum & 183 & 45,7 \\
\hline Kesinlikle katılmıorum & 73 & 18,3 \\
\hline Toplam & $\mathbf{4 0 0}$ & $\mathbf{1 0 0}$ \\
\hline
\end{tabular}

Tablo 16'da yer alan verilere göre; katılımcıların \%48,7'si yatırım yerini değiştirebileceğini, \%40’1 yatırım yerini değiştirmeyeceğini, \%11,3’ü kararsız olduğunu ifade etmiştir. Mükelleflerin çoğunluğu vergi oranları düşük olduğunda ikamet yerlerini değiştirmeyeceklerini ancak yatırım yerlerini değiştirebileceklerini belirtmektedirler. Bu sonuçtan yola çıkılarak, yatırım teşvikleri kapsamında indirimli gelir veya kurumlar vergisi uygulamalarının yatırım yeri tercihini etkileyebilme potansiyeline sahip olduğu söylenebilir.

Tablo: 16

“Türkiye'nin başka bir ilinde, daha düşük vergi oranlarının uygulandığını bilsem, yatırım yerimi değiştiririm" İfadesine Verilen Yanıtların Dağılımı

\begin{tabular}{|c|c|c|}
\hline & Frekans (S) & Yüzde (\%) \\
\hline Kesinlikle katılıyorum & 86 & 21,4 \\
\hline Katıl1yorum & 109 & 27,3 \\
\hline Kararsızım & 45 & 11,3 \\
\hline Kat1lmıorum & 123 & 30,7 \\
\hline Kesinlikle katılmıyorum & 37 & 9,3 \\
\hline Toplam & $\mathbf{4 0 0}$ & $\mathbf{1 0 0}$ \\
\hline
\end{tabular}

Tablo: 17

"Konutların kiralanmasında ve satışında elde edilen gelirlerin vergilendirilmesinde, konutun eşimle birlikte ortak mülkiyetimiz olması halinde daha az vergi ödeyeceğimi bilsem, tapuda ortak mülkiyet gösteririm" İfadesine Verilen Yanıtların Dağılımı

\begin{tabular}{|c|c|c|}
\hline & Frekans (S) & Yüzde (\%) \\
\hline Kesinlikle katıllyorum & 111 & 27,7 \\
\hline Kat1lyorum & 171 & 42,8 \\
\hline Kararsızım & 44 & 11 \\
\hline Katılmıyorum & 44 & 11 \\
\hline Kesinlikle katılmıorum & 30 & 7,5 \\
\hline Toplam & $\mathbf{4 0 0}$ & $\mathbf{1 0 0}$ \\
\hline
\end{tabular}


Ülkemizde gelir vergisi istisna tutarlarının her bir mükellef için ayrı ayrı hesaplanması dolayısıyla kira gelirleri ve değer artışı kazançları konusunda bir vergi avantajı ortaya çıkmaktadır. Tablo 17 'de yer alan verilere göre; mükelleflerin çoğunluğu $(\% 70,5)$, konutlarda ortak mülkiyetin vergiyi azalttığı bilgisine sahip olmaları durumunda bundan yararlanacaklarını belirtmektedir.

Mükelleflere, "Yatırım amaçlı ayırdığım parayı, hangi yatırım aracında (döviz, altın, hisse senedi, tahvil vs) değerlendireceğimi düşünürken, bir tanesinde vergi stopajının yüksek olması kararımı olumsuz etkiler." ifadesi yöneltilmiş ve onlardan bu ifadeye katılıp katılmadıklarını belirtmeleri istenmiştir. Tablo 18'de yer alan verilere göre; katılımcıların 256'sı (\%64) bu görüşe katıldığını, 80’i (\%20) kararsız kaldığını ve 64'ü (\%16) bu görüşe katılmadığını ifade etmiştir. Mükelleflerin çoğunluğunda yatırım aracındaki vergi oranının yüksek olup olmamasının tercihlerini etkileyebileceği görülmektedir.

Tablo: 18

"Yatırım amaçlı ayırdığım parayı, hangi yatırım aracında (döviz, altın, hisse senedi, tahvil vs) değerlendireceğimi düşünürken, bir tanesinde vergi stopajının yüksek olması kararımı olumsuz etkiler" İfadesine Verilen Yanıtların Dağılımı

\begin{tabular}{|c|c|c|}
\hline & Frekans (S) & Yüzde (\%) \\
\hline Kesinlikle katılıyorum & 75 & 18,7 \\
\hline Katıliyorum & 181 & 45,3 \\
\hline Kararsızım & 80 & 20 \\
\hline Katılmıorum & 52 & 13 \\
\hline Kesinlikle katılmıorum & 12 & 3 \\
\hline Toplam & $\mathbf{4 0 0}$ & $\mathbf{1 0 0}$ \\
\hline
\end{tabular}

Tablo: 19

"Vergi oranının düşük olduğu yatırım araçlarında paramı değerlendiririm" İfadesine Verilen Yanıtların Dağılımı

\begin{tabular}{|c|c|c|}
\hline & Frekans (S) & Yüzde (\%) \\
\hline Kesinlikle katıliyorum & 112 & 28 \\
\hline Katıllyorum & 174 & 43,4 \\
\hline Kararsızım & 57 & 14,3 \\
\hline Katılmıyorum & 49 & 12,3 \\
\hline Kesinlikle katılmıyorum & 8 & 2 \\
\hline Toplam & $\mathbf{4 0 0}$ & $\mathbf{1 0 0}$ \\
\hline
\end{tabular}

Ankete katılan mükelleflere, "Vergi oranının düşük olduğu yatırım araçlarında paramı değerlendiririm." ifadesi yöneltilmiş ve onlardan bu ifadeye katılıp katılmadıklarını belirtmeleri istenmiştir. Tablo 19'da yer alan verilere göre; 286 's1 $(\% 71,4)$ bu görüşe katıldığını, 57'si (\%14,3) kararsız kaldığını ve 57'si $(\% 14,3)$ bu görüşe katılmadığını belirtmiştir. Yani, yatırım aracında paranın değerlendirilmesi vergi oranının düşüklüğü ile ilişkilendirilmektedir. 
Ankete katılan mükelleflere, daha az vergi ödemek için kanunlardaki vergi istisnalarından yararlanmalarının doğru bir davranış olup olmadığı sorulmuş ve Tablo 20'de yer alan verilere göre; katılımcıların 283'ü $(\% 70,7)$ bu görüşün doğru olduğunu, 75'i $(\% 18,8)$ bu görüşün doğru olmadığını ve 42'si $(\% 10,5)$ kararsız kaldığını ifade etmiştir.

Tablo: 20

"Daha az vergi ödemek için kanunlardaki vergi istisnalarından yararlanmak doğrudur" İfadesine Verilen Yanıtların Dağılımı

\begin{tabular}{|c|c|c|}
\hline & Frekans (S) & Yüzde (\%) \\
\hline Kesinlikle katıllyorum & 128 & 32 \\
\hline Katıliyorum & 155 & 38,7 \\
\hline Kararsızım & 42 & 10,5 \\
\hline Katılmiyorum & 42 & 10,5 \\
\hline Kesinlikle katılmıorum & 33 & 8,3 \\
\hline Toplam & $\mathbf{4 0 0}$ & $\mathbf{1 0 0}$ \\
\hline
\end{tabular}

\subsubsection{Mükelleflerin Demografik Özelliklerine Göre Elde Edilen Çapraz Tablo Analizi}

Çapraz tablo analizinde, mükelleflerin vergi karşısındaki tutum ve davranışları ile yaş, cinsiyet, medeni durum, eğitim, iş tecrübesi, aylık gelir durumu ve mükellefiyet türü (gerçek usul-basit usul) gibi demografik özellikleri karşılaştırılmaktadır. Bu amaçla nonparametrik olan veri için ki-kare testi uygulanmıştır. Çalışma kapsamında oluşturulan hipotezler pearson anlamlılık derecesi ile \%0,5 anlamlılık düzeyinde sınanmaktadır. Buna göre; eğer hesaplanan pearson değeri (p) \%0,5'den büyük ( $\mathrm{p}>0,05)$ ise $\mathrm{H}_{0} \mathrm{kabul,} \mathrm{H}_{1}$ red edilir. Tersi durumda $(\mathrm{p}<0,05)$ ise $\mathrm{H}_{0}$ red, $\mathrm{H}_{1}$ kabul edilir (Kurtuluş, 1998: 235). Mükelleflerin tutum ve davranışları ile demografik özellikleri arasında anlamlı ilişkinin bulunduğu çapraz tablo analizlerinin birkaçına aşağıda yer verilmiştir. Çapraz tablo analizlerine ait tüm sonuçlar çalışmanın ekinde tablo şeklinde düzenlenmiştir.

Yaş grupları ile otomobil tercihinde ÖTV'nin yüksek olmasının satın alma kararını olumsuz etkileyip etkilememesi arasında bir hipotez oluşturulmuştur.

$H_{0}$ : Yaş grupları ile mükelleflerin otomobil tercihinde ÖTV'nin yüksek olmasının satın alma kararını olumsuz etkileyip etkilememesi arasında bir farklılık yoktur.

$H_{1}$ : Yaş grupları ile mükelleflerin otomobil tercihinde ÖTV'nin yüksek olmasının satın alma kararını olumsuz etkileyip etkilememesi arasında bir farklılık vardir.

Elde edilen bulgulara göre, genç ve orta yaştaki mükelleflerin çoğunluğu ÖTV'nin yüksek olması halinde otomobil satın alma kararının olumsuz etkileneceğini ifade ederken, yaşlı mükelleflerin çoğunluğu ise bu görüşe katılmadığını ifade etmiştir. Bunun 
nedenlerinden bazıları, genç ve orta yaştaki mükelleflerin birikimlerinin yaşlı mükelleflere göre daha az olması ve aynı zamanda bu yaşlardaki mükelleflerin daha tutumlu olmaları nedeniyle kazançlarını daha dikkatli harcama eğiliminde bulunmaları olabilir. Tablo 21 'de yer alan katsayı değerlerine göre; $\mathrm{p}=0,002$ ki-kare anlamlılık düzeyi $\mathrm{p}<0,05$ olduğu için, $\mathrm{H}_{0}$ red ve $\mathrm{H}_{1}$ kabul edilmiştir. Buna göre yaş grupları ile mükelleflerin otomobil tercihinde ÖTV'nin yüksek olmasının satın alma kararını olumsuz etkileyip etkilememesi arasında istatistiksel olarak anlamlı bir ilişki bulunmuştur.

Cinsiyet ile mükelleflerin herhangi bir şey alırken daha fazla vergi ödememek için tercihlerini değiştirmeleri arasında bir hipotez oluşturulmuştur.

$H_{0}$ : Cinsiyet ile mükelleflerin herhangi bir şey alırken daha fazla vergi ödememek için tercihlerini değiştirmeleri arasında bir farklılık yoktur.

$H_{1}$ : Cinsiyet ile mükelleflerin herhangi bir şey alırken daha fazla vergi ödememek için tercihlerini değiştirmeleri arasında bir farklılık vardır.

Tablo: 21

“Otomobil tercihimde, otomobilin vergisinin (Özel Tüketim Vergisi) yüksek olması, satın alma kararımı olumsuz etkiler" Ífadesine Verilen Yanıtların Dağılımı

\begin{tabular}{|c|c|c|c|c|c|c|c|c|}
\hline & \multicolumn{5}{|c|}{$\begin{array}{c}\text { Otomobil tercihimde, otomobilin vergisinin (Özel Tüketim Vergisi) } \\
\text { yüksek olması, satın alma kararımı olumsuz etkiler. }\end{array}$} & \multirow{2}{*}{ Toplam } & \multirow{2}{*}{$\begin{array}{c}\text { Ki-kare } \\
\text { Testi }\end{array}$} \\
\hline & & $\begin{array}{c}\text { Kesinlikle } \\
\text { Katıllyorum }\end{array}$ & Katılıyorum & Kararsizım & Katılmıyorum & $\begin{array}{c}\text { Kesinlikle } \\
\text { Katılmıyorum }\end{array}$ & & \\
\hline \multirow{10}{*}{ Yaş } & \multirow[b]{2}{*}{$20-29$} & 33 & 31 & 9 & 13 & 6 & 92 & \multirow{12}{*}{$\begin{array}{c}X^{2}=37,496 \\
S d=16 \\
p=0,002\end{array}$} \\
\hline & & $\% 35,9$ & $\% 33,7$ & $\% 9,8$ & $\% 14,1$ & $\% 6,5$ & $\% 100,0$ & \\
\hline & \multirow{2}{*}{ 30-39 } & 45 & 62 & 8 & 13 & 6 & 134 & \\
\hline & & $\% 33,6$ & $\% 46,3$ & $\% 6,0$ & $\% 9,7$ & $\% 4,5$ & $\% 100,0$ & \\
\hline & \multirow{2}{*}{$40-49$} & 37 & 38 & 5 & 17 & 2 & 99 & \\
\hline & & $\% 37,4$ & $\% 38,4$ & $\% 5,1$ & $\% 17,2$ & $\% 2,0$ & $\% 100,0$ & \\
\hline & \multirow{2}{*}{ 50-59 } & 9 & 22 & 4 & 11 & 5 & 51 & \\
\hline & & $\% 17,6$ & $\% 43,1$ & $\% 7,8$ & $\% 21,6$ & $\% 9,8$ & $\% 100,0$ & \\
\hline & \multirow{2}{*}{$60-69$} & 3 & 5 & 3 & 11 & 2 & 24 & \\
\hline & & $\% 12,5$ & $\% 20,8$ & $\% 12,5$ & $\% 45,8$ & $\% 8,3$ & $\% 100,0$ & \\
\hline \multirow{2}{*}{\multicolumn{2}{|c|}{ Toplam }} & 127 & 158 & 29 & 65 & 21 & 400 & \\
\hline & & $\% 31,8$ & $\% 39,5$ & $\% 7,3$ & $\% 16,3$ & $\% 5,3$ & $\% 100,0$ & \\
\hline
\end{tabular}

Tablo 22'de mükelleflerin cinsiyetlerine göre herhangi bir şey alırken daha fazla vergi ödememek için tercihlerini değiştirip değiştirmediği konusunda verdikleri cevaplar yer almaktadır. Elde edilen bulgulara göre, kadın mükelleflerin \%52,2'si bu görüşe katılırken, erkek mükelleflerin \%45,8'i bu görüşe katıldığını belirtmiştir. Buradan da anlaşılacağı üzere kadın mükelleflerin erkek mükelleflere oranla daha tutumlu oldukları ve erkek mükellefler için ihtiyaçlarının karşılanmasının verginin yüksek olup olmamasının önüne geçtiği görülmüştür. Tabloda yer alan katsayı değerlerine göre; $p=0,021$ ki-kare anlamlılık düzeyi $\mathrm{p}<0,05$ olduğu için, $\mathrm{H}_{0}$ red ve $\mathrm{H}_{1}$ kabul edilmiştir. Buna göre cinsiyet ile mükellefin herhangi bir şey alırken daha fazla vergi ödememek için tercihlerini değiştirip değiştirmemesi arasında anlamlı bir ilişkinin bulunduğu görülmüştür. 
Medeni durum ile mükelleflerin konutun eşiyle birlikte ortak mülkiyet olması durumunda daha az vergi ödeyeceğini bilmesi halinde eşlerini tapuda ortak mülkiyet gösterip göstermemesi durumları arasında bir hipotez oluşturulmuştur.

$H_{0}$ : Medeni durum ile mükelleflerin konutun eşiyle birlikte ortak mülkiyet olması durumunda daha az vergi ödeyeceğini bilmesi halinde eşlerini tapuda ortak mülkiyet gösterip göstermemesi durumları arasında bir farklılık yoktur.

$H_{1}$ : Medeni durum ile mükelleflerin konutun eşiyle birlikte ortak mülkiyet olmasl durumunda daha az vergi ödeyeceğini bilmesi halinde eşlerini tapuda ortak mülkiyet gösterip göstermemesi durumları arasında bir farklılık vardır.

Tablo: 22

"Herhangi bir şey alırken daha fazla vergi ödememek için tercihimi değiştiririm" Ifadesine Verilen Yanıtların Dağılımı

\begin{tabular}{|c|c|c|c|c|c|c|c|c|}
\hline & \multicolumn{5}{|c|}{ Herhangi bir şey alırken daha fazla vergi ödememek için tercihimi değiştiririm } & \multirow[b]{2}{*}{ Toplam } & \multirow[b]{2}{*}{$\begin{array}{c}\text { Ki-kare } \\
\text { Testi }\end{array}$} \\
\hline & & $\begin{array}{c}\text { Kesinlikle } \\
\text { Katilyyorum }\end{array}$ & Katilyorum & Kararsizim & Katilmıyorum & $\begin{array}{c}\text { Kesinlikle } \\
\text { Katılmıyorum }\end{array}$ & & \\
\hline \multirow{4}{*}{ Cinsiyet } & & 5 & 19 & 8 & 8 & 6 & 46 & \multirow{4}{*}{$\begin{array}{c}X^{2}=11,572 \\
S d=4\end{array}$} \\
\hline & Kadin & $\% 10,9$ & $\% 41,3$ & $\% 17,4$ & $\% 17,4$ & $\% 13,0$ & $\% 100,0$ & \\
\hline & \multirow{2}{*}{ Erkek } & 59 & 103 & 45 & 128 & 19 & 354 & \\
\hline & & $\% 16,7$ & $\% 29,1$ & $\% 12,7$ & $\% 36,2$ & $\% 5,4$ & $\% 100,0$ & \\
\hline \multirow{2}{*}{\multicolumn{2}{|c|}{ Toplam }} & 64 & 122 & 53 & 136 & 25 & 400 & \multirow{2}{*}{$\mathrm{p}=\mathbf{0 , 0 2 1}$} \\
\hline & & $\% 16,0$ & $\% 30,5$ & $\% 13,3$ & $\% 34,0$ & $\% 6,3$ & $\% 100,0$ & \\
\hline
\end{tabular}

Tablo: 23

"Konutların kiralanmasında ve satışında elde edilen gelirlerin vergilendirilmesinde, konutun eşimle birlikte ortak mülkiyetimiz olması halinde daha az vergi ödeyeceğimi bilsem, tapuda ortak mülkiyet gösteririm" İfadesine Verilen Yanıtların Dağılımı

\begin{tabular}{|c|c|c|c|c|c|c|c|c|}
\hline & & \multicolumn{5}{|c|}{$\begin{array}{c}\text { Konutların kiralanmasında ve satışında elde edilen gelirlerin vergilendirilmesinde, konutun } \\
\text { eşimle birlikte ortak mülkiyetimiz olması halinde daha az vergi ödeyeceğimi bilsem, tapuda ortak } \\
\text { mülkiyet gösteririm }\end{array}$} & \multirow[t]{2}{*}{ Toplam } & \multirow{2}{*}{$\begin{array}{l}\text { Ki-kare } \\
\text { Testi }\end{array}$} \\
\hline & & $\begin{array}{c}\text { Kesinlikle } \\
\text { Katılıyorum }\end{array}$ & Katılıyorum & Kararsızım & Katılmıyorum & $\begin{array}{c}\text { Kesinlikle } \\
\text { Katılmıyorum }\end{array}$ & & \\
\hline \multirow{4}{*}{$\begin{array}{l}\text { Medeni } \\
\text { durum }\end{array}$} & \multirow[b]{2}{*}{ Evli } & 85 & 142 & 25 & 33 & 23 & 308 & \multirow{6}{*}{$X^{2}=13,755$} \\
\hline & & $\% 27,6$ & $\% 46,1$ & $\% 8,1$ & $\% 10,7$ & $\% 7,5$ & $\% 100,0$ & \\
\hline & \multirow[b]{2}{*}{ Bekar } & 26 & 29 & 19 & 11 & 7 & 92 & \\
\hline & & $\% 28,3$ & $\% 31,5$ & $\% 20,7$ & $\% 12,0$ & $\% 7,6$ & $\% 100,0$ & \\
\hline \multirow{2}{*}{\multicolumn{2}{|c|}{ Toplam }} & 111 & 171 & 44 & 44 & 30 & 400 & \\
\hline & & $\% 27,8$ & $\% 42,8$ & $\% 11,0$ & $\% 11,0$ & $\% 7,5$ & $\% 100,0$ & \\
\hline
\end{tabular}

Elde edilen bulgulara göre, evli mükelleflerin \%73,7'sinin, bekâr mükelleflerin ise \%59,8'inin bu görüşe katıldıkları görülmüştür. Tablo 23 'te yer alan katsayı değerlerine göre; $\mathrm{p}=0,008$ ki-kare anlamlılık düzeyi $\mathrm{p}<0,05$ olduğu için, $\mathrm{H}_{0}$ red ve $\mathrm{H}_{1}$ kabul edilmiştir. Buna göre, medeni durum ile mükellefin daha az vergi ödeyeceklerini bilmeleri halinde eşlerini tapuda ortak mülkiyet gösterip göstermemesi arasında istatistiksel olarak anlamlı bir ilişki bulunmuştur. Yukarıdaki ifade, doğrudan medeni durum ile ilgili olduğu için evli mükelleflerin bu konuda daha fazla hassasiyet göstermesi ve bu ifadeye katılması şaşırtıcı değildir. 


\section{Sonuç}

$\mathrm{Bu}$ çalışmada mükelleflerin vergiye karşı tutum ve davranışlarını belirlemek için Isparta ili gelir vergisi mükelleflerinin vergiden kaçınma algılarını belirlemek amacıyla nicel bir araştırma yapılmıştır. Mükelleflerin vergiden kaçınma konusunda düşünceleri alınmış ve vergiden kaçınma düşüncesinin yaş, cinsiyet, medeni durum, eğitim durumu, mükellefiyet türü, aylık gelir ve iş deneyim süresine göre vergiden kaçınma düşüncesinin mükelleflerde farklılık yaratıp yaratmadığı değerlendirilmiştir.

Mükelleflerin \%88'i vergi oranlarını çok yüksek veya yüksek olarak nitelendirmiştir. Benzer şekilde, mükelleflerin yarısından fazlası $(\% 51,8)$ üzerindeki vergi yükünü ağır bulduklarını, \%29,5'i ise çok ağır bulduklarını ifade etmişlerdir. Bu sonuca paralel olarak, vergiden kaçınma nedenleri konusunda fikirlerin alındığı çoktan seçmeli soruda mükelleflerin çoğunluğu, vergi oranlarının yüksek olmasını ve vergi yükünün dağılımındaki adaletsizliği temel nedenler olarak göstermişlerdir. Vergi idaresinin yetersizliği ise etkisi en az olan neden olarak görülmüştür.

Çalışmaya katılan mükelleflerin \%52'si, yasal yollardan daha az vergi ödemeye gayret göstermenin rasyonel bir davranış olduğunu belirtmişlerdir. Buna rağmen mükelleflerin vergiden kaçınma kavramının içeriğini tam bilemeyecekleri düşünülerek, içinde "vergiden kaçınma" kavramının geçmediği ifadelere hangi düzeyde katılıp katılmadıkları sorulmuştur.

Vergi mükellefleri verginin düşük olduğu mal ve hizmet satın alma yoluna giderek vergiden kaçınabilmektedirler. Mükelleflerin satın alma tercihlerinde verginin etkisinin olup olmadığının belirlenmesi için herhangi bir satın alma düşüncesinde fiyatın içindeki vergi tutarının yüksek olmasının tercihler üzerinde etkisinin olup olmadığ sorulmuştur. Verilen yanıtlarda $\% 46,5$ ile bu düşünceye katılanların oranının daha yüksek olduğu saptanmıştır. Cinsiyete göre değerlendirildiklerinde kadın mükelleflerin \%52,2'si bu görüşe katılırken, erkek mükelleflerin $\% 45,8$ 'i ise bu görüşe katıldıkları görülmüştür.

Katma Değer Vergisi ve özellikle Özel Tüketim Vergisi otomobillerin fiyatları içinde ciddi bir paya sahiptir. Bu bağlamda somut olarak mükelleflerin otomobil tercihlerinde otomobil vergisinin yüksek olmasının satın alma kararlarını olumsuz etkileyip etkilemediği sorusu yöneltilmiş ve mükelleflerin \%71,1'i verginin satın alma kararlarında olumsuz etki ettiğini ifade etmiştir. Mükellefler yaş gruplarına göre değerlendirildiğinde, genç ve orta yaştaki mükelleflerin çoğunluğu, ÖTV'nin yüksek olması halinde otomobil satın alma kararının olumsuz etkileneceğini ifade ederken, yaşlı mükelleflerin çoğunluğunun ise bu görüşe katılmadı̆̆ 1 görülmüştür.

Vergiden kaçınmak için mükelleflerin daha düşük vergi oranlarına sahip bölgeler olduğunu bilseler, yerleşim yeri tercihini değiştirip değiştirmeyecekleri sorulduğunda yerleşim yerlerini değiştirmeyeceklerin oranının yüksek olduğu (\%64) görülmüştür. Ancak aynı soru "yatırım yerinizi değiştirir misiniz?" şeklinde sorulduğunda, mükelleflerin 
çoğunluğu $(\% 48,7)$ vergi oranları düşük olduğunda yatırım yerlerini değiştirebileceklerini belirtmektedirler.

Gelir Vergisi kanununa göre, gayrimenkul satışı ve kiralanmasından elde edilen gelirler için istisna hadleri her bir mükellef için ayrı ayrı uygulanmaktadır. Bu durum ortak mülkiyete konu olan gayrimenkuller için bir vergi avantajının doğmasına sebep olmaktadır. $\mathrm{Bu}$ amaçla vergiden kaçınma algısını tespit etmek amacıyla konutlarının kiralanmasında ve satışında elde edilen gelirlerin vergilendirilmesinde mükelleflerin konutta eşiyle birlikte ortak mülkiyetin olması durumunda az vergi ödeyeceğini bilmesi durumunda tapuda ortak mülkiyet gösterip göstermeyeceği sorulmuştur. Mükelleflerin \%70,5'lik bir çoğunluğu böyle bir durumda ortak mülkiyet fikrine sıcak baktığını belirtmiştir. Mükellefler medeni durumlarına göre değerlendirildiklerinde, evli mükelleflerin \%73,7'sinin, bekâr mükelleflerin ise \%59,8'inin bu görüşe katıldıkları görülmüştür.

Mükelleflerin vergiden kaçınma algılarını belirlemek için yatırım aracı olarak düşündüğü enstrümanlardan birine yüksek vergi uygulandığında kararlarının olumsuz etkilenip etkilenmediği sorulduğunda, mükelleflerin \%64'ü kararlarının olumsuz etkileneceğini ifade etmiştir. Bir başka deyişle, yatırım araçlarındaki vergi yükünün boyutu kişilerin yatırım tercihlerini etkilemektedir.

Son söz olarak, bu çalışmada vergi kaçırmak ve vergiden kaçınma gibi mükellef nezdinde kolaylıkla birbirinin yerine kullanılabilecek iki kavram arasında vergiden kaçınma algısı ayırt edilmeye çalışılmıştır. Ortaya çıkan sonuçlar, mükellef açısından vergiden kaçınmanın meşru ve doğru bir davranış olduğunu düşündürtmektedir. Bunun dışında, vergiden kaçınma algısının demografik değişkenler ile ilişkisi bağlamında, özellikle yaş, cinsiyet, eğitim durumu değişkenleri ile mükelleflerin vergiden kaçınma algıları arasında istatistiksel olarak anlamlı ilişkiler daha fazla ortaya çıkmıştır. Buna karşılık, medeni durum, iş tecrübesi değişkenleri ile vergiden kaçınma algıları arasında daha az anlamlı ilişkiye rastlanmıştır. Mükellefin gerçek veya basit usulde vergilendiriliyor olması veya aylık gelir durumu ise, vergiden kaçınma algısına etki etmemektedir.

\section{Kaynaklar}

Alkan, A. (2009), "Vergi Bilinci ve Vergi Uygulamaları Karşısında Mükellef Davranışlarının Tespiti: Zonguldak İli Örneği”, Zonguldak Karaelmas Üniversitesi Sosyal Bilimler Enstitüsü Yayınlanmamış Yüksek Lisans Tezi.

Akdoğan, A. (2011), Kamu Maliyesi, 14. Bask1, Gazi Kitabevi.

Aktan, C.C. (2012), Vergi Psikolojisinin Temelleri ve Vergi Ahlakl, <http://www.ceis.org.tr/dergi/2012ocak/makale2.pdf>, 25.02.2015.

Asante, S. \& A. Baba (2011), “Tax Compliance Among Self-Employed in Ghana: Do Demographic Characteristics Matter?", International Business and Management, 3(1), 86-91.

Aşan, S. (2014), "Mükellef ve Kamu Otoritesi Açısından Vergi Ahlakının Değerlendirilmesi”, Journal of Life Economics, 1/2014, 69-79. 
Bowler, T. (2009), “Countering Tax Avoidance in The Uk: Which Way Forward?", The Institute for Fiscal Studies, TLRC Discussion Paper No. 7.

Çataloluk, C. (2008), "Vergi Karşısında Mükelleflerin Tutum ve Davranışları”, Selçuk Üniversitesi Sosyal Bilimler Dergisi, S.20, 213-228.

Çiçek, H. \& M. Karakaş \& A. Yıldız (2008), Güneydoğu Anadolu Bölgesi’nde Vergi Yükümlülerinin Vergiyi Algılama ve Tutum Analizi: Bir Alan Araştırması, Maliye Bakanlığı Strateji Geliştirme Başkanlığı Yayın No: 2008/381.

Devos, K. (2008), “Tax Evasion Behaviour and Demographic Factors: An Exploratory Study in Australia", Revenue Law Journal, 18(1), 1-43.

Edizdoğan, N. \& Ö. Çetinkaya \& E. Gümüş (2012), Kamu Maliyesi, 4. Baskı, Ekin Yayınevi. Eker, A. (1999), Kamu Maliyesi, 3. Bask1, İzmir: Anadolu Matbaacılık.

Evans, C. (2009), “Containing Tax Avoidance: Anti-Avoidance Strategies”, in: John G. Head Richard E. Krever, (Ed.), Tax Reform in The 21st Century: A Volume in Memory of Richard Musgrave, Chapter 17, Kluwer Law International, 529-562.

Gök, A.K. (2007), Vergi Direncinin Gelişimi, Marmara Üniversitesi İ.I.B.F. Dergisi, XXII(1), 143163.

Hashimzade, N. \& G.D. Myles \& F. Page \& M.D. Rablen (2011), "Social Networks and Occupational Choice: The Endogenous Formation of Attitudes and Beliefs about Tax Compliance", Journal of Economic Psychology, 1-31.

Hoque, Md. J. \& M.Z.H. Bhuiyan \& A. Ahmad (2013), "Tax Evasion and Avoidance Crimes - A Study on Some Corporate Firms of Bangladesh”, Proceedings of 6th International Business and Social Science Research Conference, World Business Institute Australia, 115 .

İnanç, M. (2012), "Vergi Ahlakını Şekillendiren Faktörlerin Vergiden Kaçınma ve Vergi Kaçırma Üzerindeki Etkisi: Biga Örneği”, Çanakkale Onsekiz Mart Üniversitesi Sosyal Bilimler Enstitüsü Yayınlanmamış Yüksek Lisans Tezi.

İpek, S. \& İ. Kaynar (2009), "Demografik Faktörlerin Vergi Uyumuna Etkisi: Bir Anket Çalışmasının Sonuçları”, Maliye Dergisi, S.157, 116-130.

Jackson, B.R., \& V.C. Milliron (1986), "Tax compliance research: Findings, problems, and prospects", Journal of Accounting Literature, 5, 125-165; akt: J. Kasipillai, \& H. Abdul Jabbar (2006), Gender and Ethnicity Differences in Tax Compliance, Asian Academy of Management Journal, 11(2), 73-88.

Jackson, B.R. \& V.C. Milliron (2002), “Tax Compliance Research: Findings, Problems and Prospects”, in: S. James, (Ed.), Taxation: Critical Perspectives on the World Economy, Routledge, London and New York, 56-101.

Kurtuluş, K. (1998), Pazarlama Araştırmaları, 6. Baskı, İstanbul: Avcıol Basım Yayın.

Lampreave, P. (2013), “Anti-Tax Avoidance Measures in China and India: An Evaluation of Specific Court Decisions", Bulletin For International Taxation, 49-60.

Nadaroğlu, H. (1996), Kamu Maliyesi Teorisi, Beta Basım Yayım.

O'Shea, T. (2010), “Tax Avoidance and Abuse of EU Law”, The EC Tax Journal, C.11, 77-115.

Review of Business Taxation (1999), A Tax System Redesigned, Canberra: Treasury at s. 6.2(c), akt. L. Zhang, (2007), Tax Avoidance: Causes and Solutions, Master of Business, Auckland University of Technology. 
Sandmo, A. (2004), “The Theory of Tax Evasion: A Retrospective View”, Norwegian School of Economics and Business Administration, 1-31.

Saraçoğlu, F. (2008), "Yaş - Cinsiyet - Medeni Durum ve Eğitim Durumunun Vergiye Karş1 Tutum Üzerine Etkilerinin Anket Sonuçları Çerçevesinde Değerlendirilmesi”, KMU İ̈BF Dergisi, 10/15, 16-34.

Schneider, F. \& E. Kirchler \& B. Maciejovsky (2001), "Social Representations on Tax Avoidance, Tax Evasion, and Tax Flight: Do Legal Differences Matter?", Department of Economics of Johannes Kepler University, Working Paper No. 0104, 1-27.

Şin, S. (2005), Avrupa Birliği ve Türkiye'de Vergi Yapısı, Denetimi ve İdari İşlemlerde Mükellef Haklart, İstanbul Ticaret Odas1, Yayın No: 2005-17.

Taşkın, Y. (2010), "Vergi Psikolojisi ve Vergiye Karşı Mükellef Tepkileri”, İstanbul Üniversitesi İktisat Fakültesi Maliye Araştırma Merkezi Konferanslart, 68-90.

Taylor, M.B. (2006), Tax Policy and Tax Avoidance: The General Anti-Avoidance Rule from a Tax Policy Perspective, Master of Laws, The University of British Columbia.

Tittle, C.R. (1980), "Sanctions and Social Deviance: The Question of Deterrence”, NewYork: Praeger, akt. Devos, K. (2008), Tax Evasion Behaviour and Demographic Factors: An Exploratory Study in Australia, Revenue Law Journal, 18(1), 1-43.

Tooma, R.A. (2008), Legislating Against Tax Avoidance, Amsterdam: IBFD.

Vogel, J. (1974), "Taxation and Public Opinion in Sweden: An Interpretation of Recent Survey Data”, National Tax Journal, 27; akt. N. Ömürbek, \& H.G. Çiçek \& S. Çiçek (2007), "Vergi Bilinci Üzerine Bir İnceleme: Üniversite Öğrencileri Üzerinde Yapılan Anketin Bulguları", Maliye Dergisi, 153, 102-122.

Webley, P. (1991), Tax Evasion: An Experimental Approach, Cambridge University Press.

Yeniçeri, H. (2004), "Beyan Esasına Dayanan Vergilerde Vergi Kayıp ve Kaçaklarının Psikolojik Nedenlerinin Tespitine Yönelik Bir Araştırma”, 19. Türkiye Maliye Sempozyumu, 908927.

Yenigün, Y. (2012), "Vergi Bilinci ve Vergi Uygulamaları Karşısında Mükelleflerin Davranışları: İstanbul Örneği”, Süleyman Demirel Üniversitesi Sosyal Bilimler Enstitüsü, Yayınlanmamış Yüksek Lisans Tezi.

Yıldız, Y. \& S. Bedir \& K. Karabulut (2013), “Türkiye'de Gelir Üzerinden Alınan Vergi Oranlarının Değerlendirilmesi: Bir Anket Uygulamasının Sonuçları”, Vergi Siyaseti, 127-152.

Yıldız, Y. (2011), “Türkiye’de Vergi Oranlarının Uygunluğu Üzerine Bir Uygulama”, Atatürk Üniversitesi Sosyal Bilimler Enstitüsü, Yayınlanmamış Yüksek Lisans Tezi. 
EK:

Mükelleflerin Demografik Özelliklerine Göre Elde Edilen Sonuçlar

\begin{tabular}{|c|c|c|c|c|c|c|c|}
\hline Önermeler & $\stackrel{n}{\pi}$ & 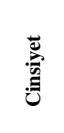 & 冚总 & 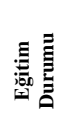 & 事 & 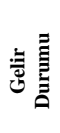 & 窇: \\
\hline Yasal yollardan daha az vergi ödemeye çalışmak rasyonel bir davranıştır. & $\begin{array}{c}\mathrm{H}_{0} \\
\text { kabul }\end{array}$ & $\begin{array}{c}\mathrm{H}_{0} \\
\text { kabul }\end{array}$ & $\begin{array}{c}\mathrm{H}_{0} \\
\text { kabul }\end{array}$ & $\begin{array}{c}\mathrm{H}_{0} \\
\text { kabul }\end{array}$ & $\begin{array}{c}\mathrm{H}_{0} \\
\text { kabul }\end{array}$ & $\begin{array}{c}\mathrm{H}_{0} \\
\text { kabul }\end{array}$ & $\begin{array}{c}\mathrm{H}_{0} \\
\text { kabul }\end{array}$ \\
\hline Vergiden kaçındığımda rahatsız olurum. & $\begin{array}{c}\mathrm{H}_{0} \\
\text { kabul }\end{array}$ & $\begin{array}{c}\mathbf{H}_{1} \\
\text { kabul }\end{array}$ & $\begin{array}{c}\mathrm{H}_{0} \\
\text { kabul }\end{array}$ & $\begin{array}{c}\mathbf{H}_{1} \\
\text { kabul }\end{array}$ & $\begin{array}{c}\mathrm{H}_{1} \\
\text { kabul }\end{array}$ & $\begin{array}{c}\mathrm{H}_{0} \\
\text { kabul }\end{array}$ & $\begin{array}{c}\mathrm{H}_{0} \\
\text { kabul }\end{array}$ \\
\hline Herhangi bir şey alırken daha fazla vergi ödememek için tercihimi değiştiririm. & $\begin{array}{c}\mathrm{H}_{0} \\
\text { kabul }\end{array}$ & $\begin{array}{c}\mathrm{H}_{1} \\
\text { kabul }\end{array}$ & $\begin{array}{c}\mathrm{H}_{0} \\
\text { kabul }\end{array}$ & $\begin{array}{c}\mathrm{H}_{0} \\
\text { kabul }\end{array}$ & $\begin{array}{c}\mathrm{H}_{0} \\
\text { kabul }\end{array}$ & $\begin{array}{c}\mathrm{H}_{0} \\
\text { kabul }\end{array}$ & $\begin{array}{c}\mathrm{H}_{0} \\
\text { kabul }\end{array}$ \\
\hline $\begin{array}{l}\text { Otomobil tercihimde, otomobilin vergisinin (Özel Tüketim Vergisi) yüksek olması, } \\
\text { satın alma kararımı olumsuz etkiler. }\end{array}$ & $\begin{array}{c}\mathrm{H}_{1} \\
\text { kabul }\end{array}$ & $\begin{array}{c}\mathrm{H}_{1} \\
\text { kabul }\end{array}$ & $\begin{array}{c}\mathrm{H}_{0} \\
\text { kabul }\end{array}$ & $\begin{array}{c}\mathrm{H}_{0} \\
\text { kabul }\end{array}$ & $\begin{array}{c}\mathrm{H}_{0} \\
\text { kabul }\end{array}$ & $\begin{array}{c}\mathrm{H}_{0} \\
\text { kabul }\end{array}$ & $\begin{array}{c}\mathrm{H}_{0} \\
\text { kabul }\end{array}$ \\
\hline $\begin{array}{l}\text { Türkiye'nin başka bir ilinde, daha düşük vergi oranlarının uygulandığını bilsem, } \\
\text { yerleşim yerimi değiştiririm. }\end{array}$ & $\begin{array}{c}\mathbf{H}_{1} \\
\text { kabul }\end{array}$ & $\begin{array}{c}\mathbf{H}_{1} \\
\text { kabul }\end{array}$ & $\begin{array}{c}\mathrm{H}_{0} \\
\text { kabul }\end{array}$ & $\begin{array}{c}\mathrm{H}_{0} \\
\text { kabul }\end{array}$ & $\begin{array}{c}\mathrm{H}_{0} \\
\text { kabul }\end{array}$ & $\begin{array}{c}\mathrm{H}_{0} \\
\text { kabul }\end{array}$ & $\begin{array}{c}\mathrm{H}_{0} \\
\text { kabul }\end{array}$ \\
\hline $\begin{array}{l}\text { Türkiye'nin başka bir ilinde, daha düşük vergi oranlarının uygulandığını bilsem, } \\
\text { yatırım yerimi değiştiririm. }\end{array}$ & $\begin{array}{c}\mathrm{H}_{0} \\
\text { kabul }\end{array}$ & $\begin{array}{c}\mathbf{H}_{1} \\
\text { kabul }\end{array}$ & $\begin{array}{c}\mathrm{H}_{0} \\
\text { kabul }\end{array}$ & $\begin{array}{c}\mathrm{H}_{0} \\
\text { kabul }\end{array}$ & $\begin{array}{c}\mathrm{H}_{0} \\
\text { kabul }\end{array}$ & $\begin{array}{c}\mathrm{H}_{0} \\
\text { kabul }\end{array}$ & $\begin{array}{c}\mathrm{H}_{0} \\
\text { kabul }\end{array}$ \\
\hline $\begin{array}{l}\text { Konutların kiralanmasında ve satışında elde edilen gelirlerin vergilendirilmesinde, } \\
\text { konutun eşimle birlikte ortak mülkiyetimiz olması halinde daha az vergi } \\
\text { ödeyeceğimi bilsem, tapuda ortak mülkiyet gösteririm. }\end{array}$ & $\underset{\text { kabul }}{\mathrm{H}_{0}}$ & $\underset{\text { kabul }}{\mathrm{H}_{0}}$ & $\underset{\text { kabul }}{\mathbf{H}_{1}}$ & $\begin{array}{c}\mathbf{H}_{1} \\
\text { kabul }\end{array}$ & $\begin{array}{c}\mathrm{H}_{0} \\
\text { kabul }\end{array}$ & $\begin{array}{c}\mathrm{H}_{0} \\
\text { kabul }\end{array}$ & $\begin{array}{c}\mathrm{H}_{0} \\
\text { kabul }\end{array}$ \\
\hline $\begin{array}{l}\text { Yatırım amaçlı ayırdığım parayı, hangi yatırım aracında (döviz, altın, hisse senedi, } \\
\text { tahvil vs) değerlendireceğimi düşünürken, bir tanesinde vergi stopajının yüksek } \\
\text { olması kararımı olumsuz etkiler. }\end{array}$ & $\underset{\text { kabul }}{\mathbf{H}_{1}}$ & $\begin{array}{c}\mathrm{H}_{0} \\
\text { kabul }\end{array}$ & $\begin{array}{c}\mathrm{H}_{0} \\
\text { kabul }\end{array}$ & $\begin{array}{c}\mathrm{H}_{0} \\
\text { kabul }\end{array}$ & $\begin{array}{c}\mathrm{H}_{0} \\
\text { kabul }\end{array}$ & $\begin{array}{c}\mathrm{H}_{0} \\
\text { kabul }\end{array}$ & $\begin{array}{c}\mathrm{H}_{0} \\
\text { kabul }\end{array}$ \\
\hline Vergi oranının düşük olduğu yatırım araçlarında paramı değerlendiririm. & $\begin{array}{c}\mathrm{H}_{0} \\
\text { kabul }\end{array}$ & $\begin{array}{c}\mathrm{H}_{0} \\
\text { kabul }\end{array}$ & $\begin{array}{c}\mathrm{H}_{0} \\
\text { kabul }\end{array}$ & $\begin{array}{c}\mathrm{H}_{0} \\
\text { kabul }\end{array}$ & $\begin{array}{c}\mathrm{H}_{0} \\
\text { kabul }\end{array}$ & $\begin{array}{c}\mathrm{H}_{0} \\
\text { kabul }\end{array}$ & $\begin{array}{c}\mathrm{H}_{0} \\
\text { kabul }\end{array}$ \\
\hline Daha az vergi ödemek için kanunlardaki vergi istisn & $\begin{array}{c}\mathrm{H}_{1} \\
\text { kabul }\end{array}$ & $\begin{array}{c}\mathrm{H}_{0} \\
\text { kabul }\end{array}$ & $\begin{array}{c}\mathrm{H}_{0} \\
\text { kabul }\end{array}$ & $\begin{array}{c}\mathrm{H}_{0} \\
\text { kabul }\end{array}$ & $\begin{array}{c}\mathrm{H}_{0} \\
\text { kabul }\end{array}$ & $\begin{array}{c}\mathrm{H}_{0} \\
\text { kabul }\end{array}$ & $\begin{array}{c}\mathrm{H}_{0} \\
\text { kabul }\end{array}$ \\
\hline
\end{tabular}

Ho kabul: Önerme ile demografik değişken arasında anlamlı bir ilişsi bulunmamaktadır.

$\boldsymbol{H}_{1}$ kabul: Önerme ile demografik değişken arasında anlamlı bir iliş̧i bulunmaktadır.

\section{ISPARTA ILINDEKI GELIR VERGISI MÜKELLEFLERININ VERGIDEN KAÇINMA ALGILARI ÜZERINE AMPIRIKK BİR DEĞERLENDİRME}

$\mathrm{Bu}$ anket çalışması ile Isparta ilindeki gelir vergisi mükelleflerinin vergiden kaçınma konusunda düşüncelerinin ölçülmesi amaçlanmaktadır. Verdiğiniz bilgiler ve belirtmiş olduğunuz düşünceler tamamen akademik bir amaçla, hazırlanacak bilimsel çalışmada kullanılacaktır.

\section{ÖNBILLGi}

Vergiden Kaçınmak, vergi kanunlarını ihlal etmeden daha az vergi ödemenin yollarını araştırmaktır.

\section{Demografik Sorular:}

\section{Yaşınız?}

( ) 20-29 ( ) 30-39 ( ) 40-49 ( ) 50-59 ( ) 60-69

\section{Cinsiyetiniz?}

( ) Kadın ( ) Erkek

\section{Medeni Durumunuz?}

( ) Evli ( ) Bekâr 


\section{Eğitim Durumunuz?}

( ) İlkokul ( ) Ortaokul ( ) Lise ( ) Ön lisans ( ) Lisans ( ) Yüksek lisans -Doktora

\section{Kaç yıllık iş tecrübesine sahipsiniz?}

( ) 0-5 y1l ( ) 6-10 y1l ( ) 11-15 y1l ( ) 16-20 y1l ( ) 25 y1ldan fazla

\section{Aylık ortalama gelir durumunuz nedir?}

( ) 500-999 ( ) 1000-1999 ( ) 2000-2999 ( ) 3000-3999 ( ) 4000 ve üzeri

\section{Araştırma Konusu İle İlgili Sorular:}

\section{Mükellefiyet türünüz?}

( ) GERÇEK USUL ( ) BASİT USUL

2. Ülkemizde vergi oranları size göre yüksek midir?

( ) Çok yüksek ( ) Yüksek ( ) Normal ( ) Düşük ( ) Çok düşük

\section{Kendi üzerinizdeki toplam vergi yükünü nasıl hissediyorsunuz?}

( ) Çok ağır ( ) Ağır ( ) Normal ( ) Hafif

\section{En çok hangi verginin daha fazla yük oluşturduğunu düşünüyorsunuz?}

( ) Gelir Vergisi ( ) Katma Değer Vergisi ( ) Özel Tüketim Vergisi

\section{Sizce mükellefler en çok hangi sebeple/sebeplerle vergiden kaçınır?}

( ) İktisadi güçlerinde azalmaya neden olduğu için

( ) Vergi yükünün dağılımında ortaya çıkan adaletsizlik nedeniyle

( ) Vergi bilinci ve vergi ahlakının yeterince yerleşmemiş olması

( ) Vergi oranlarının yüksek olması

( ) Devlete ödenen vergilerin kamu hizmeti olarak geri dönmemesi

( ) Vergi mevzuatının karmaşıklığı

( ) Vergi denetiminin yetersizliği

() Vergi idaresinin yetersizliği

( ) Vergiden kaçınmanın rasyonel bir davranış olması

\section{Aşağıda yazılı olan ifadelere ilişkin görüşlerinizi belirtiniz.}

\begin{tabular}{|c|c|c|c|c|c|}
\hline & 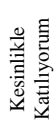 & 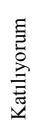 & 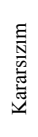 & 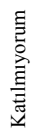 & 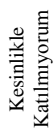 \\
\hline \multicolumn{6}{|l|}{ Yasal yollardan daha az vergi ödemeye çalışmak rasyonel bir davranıştır. } \\
\hline \multicolumn{6}{|l|}{ Vergiden kaçındığımda rahatsız olurum. } \\
\hline \multicolumn{6}{|l|}{ Herhangi bir şey alırken daha fazla vergi ödememek için tercihimi değiştiririm. } \\
\hline \multicolumn{6}{|l|}{$\begin{array}{l}\text { Otomobil tercihimde, otomobilin vergisinin (Özel Tüketim Vergisi) yüksek olması, satın alma kararımı olumsuz } \\
\text { etkiler. }\end{array}$} \\
\hline \multicolumn{6}{|l|}{$\begin{array}{l}\text { Türkiye'nin başka bir ilinde, daha düşük vergi oranlarının uygulandığını bilsem, yerleşim yerimi değiştiririm. } \\
\text { Türkive'nin baska bir ilinde, daha düsük vergi oranlarının uygulandığını bilsem, vatırım verimi değistiririm. }\end{array}$} \\
\hline \multicolumn{6}{|l|}{ Türkiye'nin başka bir ilinde, daha düşük vergi oranlarının uygulandığını bilsem, yatırım yerimi değiştiririm. } \\
\hline \multicolumn{6}{|l|}{$\begin{array}{l}\text { Konutların kiralanmasında ve satışında elde edilen gelirlerin vergilendirilmesinde, konutun eşimle birlikte ortak } \\
\text { mülkiyetimiz olması halinde daha az vergi ödeyeceğimi bilsem, tapuda ortak mülkiyet gösteririm. }\end{array}$} \\
\hline \multicolumn{6}{|l|}{$\begin{array}{l}\text { Yatııım amaçlı ayırdığım parayı, hangi yatırım aracında (döviz, altın, hisse senedi, tahvil vs) değerlendireceğimi } \\
\text { düşünürken, bir tanesinde vergi stopajının yüksek olması kararımı olumsuz etkiler. }\end{array}$} \\
\hline \multicolumn{6}{|l|}{ Vergi oranının düşük olduğu yatırım araçlarında paramı değerlendiririm. } \\
\hline Daha az vergi ödemek için kanunlardaki vergi istisnalarından yararlanmak doğrudur. & & & & & \\
\hline
\end{tabular}

